\title{
1 An unfortunate accident of geography: badlands and the ANZAC Sector, Gallipoli, April-December 1915
}

\author{
Peter Doyle \\ Department of Earth Sciences, University College London, Gower Street, London WC1E \\ 6BT, UK \\ doyle268@btinternet.com, +44 (0) 7754152063 (office)
}

\begin{abstract}
Gallipoli continues to be a cause célèbre for those seeking to assign blame for this ill-fated military campaign fought against the Ottoman Empire from April to December 1915. Variously blamed are weak generals, poor planning and preparation - and even inadequate topographical mapping. Intended to assist the Allied naval fleet in breaking through the Dardanelles Straits, thereby threatening the Ottoman Capital of Constantinople (and, it was hoped, forcing the Ottomans out of the war), the military campaign was certainly hastily conceived and underresourced. Commencing on 25 April 1915 as an amphibious landing, the campaign soon degenerated into a desperate struggle, as the Allies attempted in vain to break out of tightly constrained beachheads. This study investigates the role of terrain in the warfare of the ANZAC (Australian and New Zealand Army Corps) Sector, from initial landings in April, to attempted breakout in August. At ANZAC, an 'unfortunate accident of geography' brought, dry, mostly fine-grained Pliocene sediments to the coast. An upland area created by the North Anatolian Fault System, the fine sediments were (and are) quickly weathered and eroded to form topographically complex gullied surfaces. This would be the almost hopeless battleground of the Australians and New Zealanders in April-December 1915. With the Ottomans holding a firm grip on the ridge top, the ANZAC troops were constrained to a small, deeply dissected and mostly waterless sector of the scarp slope of the Sari Bair Plateau and ridge system. The war here would be hard fought and bloody, with geology having a major impact on its outcome; the withdrawal of ANZAC troops in December 1915.
\end{abstract}

Keywords Dardanelles, Gallipoli, amphibious landings, badland topography, Ottomans, ANZAC, water supply, trenches, tunnelling 


\section{Introduction}

The Dardanelles, a narrow passageway between European and Asian Turkey, is a tightly-constrained waterway that was created by movement along the still seismically-active North Anatolian Fault system. This strategic waterway connects the Aegean Sea and Mediterranean with the Sea of Marmara and ultimately, through the Bosphorous, to the Black Sea, and has been a point of military interest for centuries. In European Turkey, the shores of the Dardanelles are guarded by the Gallipoli Peninsula, a narrow finger of land named after its principal settlement (Gelibolu, or Gallipoli). Opposing this is the Asiatic shore, the Aegean expression of the great Anatolian Peninsula, the greater part of modern Turkey, and the heart of the ailing Ottoman Empire in 1915.

Constantinople, (now the modern city of Istanbul), sits astride the Bosphorous and guards the entrance to the Black Sea, thereby controlling entry to the winter ports of Russia. The city had been coveted for centuries, particularly by the old enemies of Greece and Russia. With the Ottoman Empire finally committed to the Central Powers late in 1914, the sights of the Allies turned once again to the Dardanelles and Constantinople, with the hope that the Ottomans could be persuaded by a show of arms to retreat from their alliance, and sue for peace - thereby allowing Russia to be supplied from the south through the Dardanelles and Bosphorous, and on to the Black Sea. That show of arms was to be by an Anglo-French naval demonstration, with out-dated ships pitted against the fortresses of the Dardanelles, the intention being for these naval vessels to press on regardless, and appear off the Golden Horn in Constantinople - thereby, it was hoped, forcing the hand of the Ottomans (Aspinall-Oglander 1929). Long-fortified, the idea of squeezing a fleet of ships between the beetling brows of the shores of the Dardanelles had exercised the mind of the military of many nations for centuries, particularly so in the complex diplomacies of two centuries before the Great War.

Arguably doomed to failure from its inception, the Naval Campaign began on 19 February and was abandoned just under a month later, on 18 March 1915, partly a result of the severe loss of men and capital ships to minefields. The next phase was the invasion of the Peninsula, with the sole purpose of removing enemy minefields and shore batteries, thereby allowing the ships once again to pass through the straits. It was not intended, however, that ground forces would press on to capture Constantinople; that would still be left to the Navy (Aspinall-Oglander 1929; Rhodes James 1965; Travers 2001; Carlyon 2003; Prior 2009; Doyle 2011). Thus, on 25 April 1915, landings were made on several of the beaches at Gallipoli in two main sectors: Cape Helles at the tip of the Peninsula, scene of the landings of the British 29th Division, (most recently discussed by Doyle 2008), and farther up the coast, in the 'badland' topography of what became known as the ANZAC sector (Fig. 1.1), named after the Australian \& New Zealand Army Corps that landed there. 


\section{Gallipoli: Landing places}

\section{April \\ 1915: \\ Military \\ landings to \\ silence guns}

Possible landing places:

\section{Bulair}

2. 'Asiatic Shore'

3.Gaba Tepe

4.Cape Helles

5.Suvla Bay
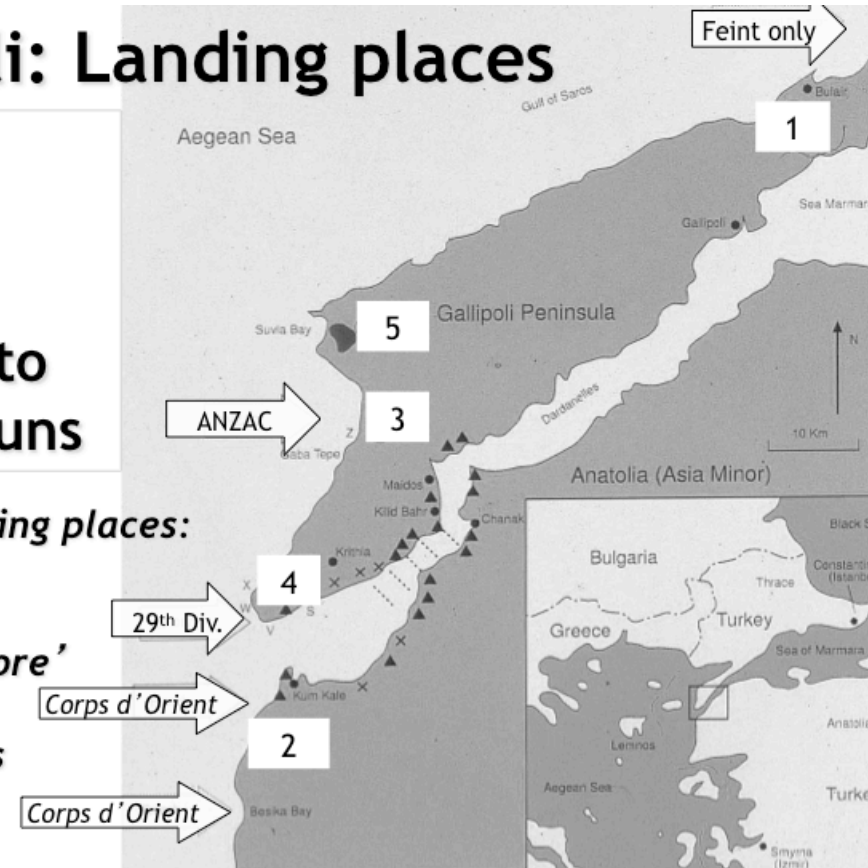

Fig. 1.1 The potential landing sites at Gallipoli; the landings were planned to 'silence the guns' and permit the removal of the Ottoman minefields, so hazardous to the passage of the Allied ships. Landings made on 25 April are indicated by the main arrows. (Based on illustration in Doyle and Bennett 1999).

For all the attention focused upon the ANZAC Sector (e.g., see Rhodes James 1965; Travers 2001; Carlyon 2003; Prior 2009; Crawley 2014 and books therein), there have been few detailed studies of the military geography of this important part of the Gallipoli battlefield. Some aspects of its military geology have been discussed by Doyle \& Bennett $(1999,2002)$, and the topographical intelligence gathered for the landings has been described by Chasseaud \& Doyle (2004). This paper examines the role of terrain in the warfare of the ANZAC Sector, from initial landings in April, to the development of trench warfare. At ANZAC, what might be termed an 'unfortunate accident of geography' brought, dry, mostly finegrained Pliocene sediments to the coast, the only location upon the Peninsula where this is the case. An upland area due to the North Anatolian Fault System, the fine sediments were (and are) quickly weathered and eroded to form topographically complex gullied surfaces. This created an almost hopeless battleground for Australians and New Zealanders during the latter part of 1915. With the Ottomans holding a firm grip on the ridge top, ANZAC troops were constrained to a small, deeply dissected and mostly waterless sector of the scarp slope of the Sari Bair Plateau and ridge system. The war here would be hard fought and bloody, with the local geology having a major impact on its outcome. 


\section{Campaign summary}

The land-based Gallipoli campaign was planned originally for 23 April 1915, following the failure of the naval engagement, and concerns over the continued loss of ships and naval personnel. Troops intended for the landings were drawn from Britain (29th and Royal Naval divisions), Australia, New Zealand (Australian and Zealand Army Corps: ANZAC), and France (Corps Expéditionnaire d'Orient), gathered together on the Greek islands of Lemnos and Imbros under the overall command of General Sir Ian Hamilton.

It was understood by both sides that there were a limited number of locations, a factor that is typical of all amphibious operations (Galgano 2005), determined largely by the disposition of major terrain elements, where a landing could be successfully executed: (1) in the northern part of the Peninsula near Bulair, the narrowest part of the isthmus connecting Gallipoli with the rest of Thrace; (2) on the Aegean coast of Anatolia-known in contemporary accounts as the Asiatic shore - notably at Kum Kale at the entrance to the Dardanelles; (3) on either side of the promontory known as Gaba Tepe, in a depression separating the two main massifs of the southern peninsula; (4) at the narrow beaches of Cape Helles, threatening the southern slopes of the Kilid Bahr Plateau; and (5) at Suvla Bay (Fig. 1.1; Nevinson 1920; Aspinall-Oglander 1929; Callwell 1929; Rhodes James 1965; Travers 2001; Chasseaud \& Doyle 2004; Prior 2009).

As described by Doyle \& Bennett $(1999,2002)$ (and the commander himself, Hamilton 1920) the Allied commander rejected both Bulair and the Asiatic shore as main landing sites, due to the strength of the enemy positions there and the increased proximity of Ottoman troops. Instead, a concentration of effort was to be made in the southwestern part of the peninsula, the intention being the capture the Kilid Bahr Plateau, which overlooked the main fort of the same name, and the narrows of the Dardanelles. This, it was hoped, would achieve the main objectives of the landing, the support of naval operations. Suvla Bay was ruled out as it was too far away from the Kilid Bahr Plateau to be of value, and because there was little reliable information about its terrain characteristics. The main landings were therefore to be made at the southern end of the Peninsula at Cape Helles, and on the west coast at Gaba Tepe, in what would become known as the ANZAC Sector (Fig. 1.1).

The German commander of the Ottoman troops, General Liman von Sanders considered the most likely landing places to be Bulair and the Anatolian Coast; the former because of its strategic position in controlling the neck of the peninsula, the latter because of the possibility provided by its relatively wide beaches. It was for this reason that he created heavily fortified positions in these areas. Von Sanders also realised the threat from attacks at Gaba Tepe and Cape Helles; the former because of the low ground crossing the peninsula between the Sari Bair and Kilid Bahr plateaux, threatening Maidos, the latter because of the long slope up from the beaches to the peak of Achi Baba which could easily be threatened by naval gunfire. Not surprisingly, all of these areas were protected by extensive trenches and 
barbed wire entanglements in the month preceding the Allied landings in 1915 (Aspinall-Oglander 1929; Rhodes James 1965; Doyle \& Bennett 1999, 2002; Travers 2001; Chasseaud \& Doyle 2004; Prior 2009; Doyle 2011).

The Cape Helles landings were made by the men of the British 29th Division at five beaches, code lettered S, V, W, X, Y. The landings at S, X and Y were virtually unopposed, but due to poor communications, the tactical advantages of the situation were not exploited. The landings at $\mathrm{V}$ and $\mathrm{W}$ met fierce opposition from the Turks in their well-prepared positions (Aspinall-Oglander 1929; Rhodes James 1965; Doyle 2008). The landings north of Gaba Tepe at $Z$ beach were to be made by the men of the ANZAC Corps. They were to be beached from towed open boats commanded by junior naval officers who had orders to stay in set positions as they approached the shore. Constant readjustment to retain these positions, and a gradual northwards drift, meant that the troops landed at the northern extremity of the beaches, a feature that has received much comment and discussion (e.g. see Aspinall-Oglander 1929; Rhodes James 1965; Carlyon 2003; Doyle 2011). In fact, the landing zone was not as tightly constrained as has been previously discussed (see Prior 2009 for discussion), and the landings were actually spread out along the beach, in front of what would become known as Plugge's Plateau, and close to the small cove, now known as Anzac Cove.

After 25 April 1915, the 'Battle of the Beaches', static trench positions similar to those of the Western Front developed. In the ANZAC Sector, the Allied objectives were the summit of the Sari Bair ridge, though some troops did manage to reach the subsidiary peak of Chunuk Bair in the opening days of the campaign. Very quickly the ANZAC troops became committed to static trench warfare, although some actions, such as the battles for the Lone Pine and the Nek in August of the same year, gained legendary status in Australia and New Zealand. However, throughout the campaign the troops at ANZAC were in a very difficult position, cramped by the narrowness of the beach and hemmed in by the precipitous slopes.

Following the failure of the summer offensives (Crawley 2014), and the replacement of General Sir Ian Hamilton as Allied Commander, it realised by his replacement, Sir Charles Munro, that it would be impossible to sustain the campaign, break the stalemate, and achieve the strategic objectives without a significant diversion of men and resources away from the Western Front. For these reasons, first a partial, and then a complete, withdrawal were planned. These took place, with complete success and few casualties, in December 1915 and January 1916.

\section{Geological setting of the Gallipoli Peninsula}

Doyle $(1999,2002,2008)$ has provided an overview of the geology and topographical features of Gallipoli, which is the basis, together with the available geological map (Ternek et al. 1987) for this summary. The Gallipoli Peninsula forms

part of the Alpine Pontide range, with a strong east-west structural grain, and 
comprises ancient crystalline massifs developed in Anatolia, and folded Mesozoic-Cenozoic sediments in Thrace and basement margins of Anatolia. The most dominant feature is the North Anatolian Fault zone, separating the European and Anatolian plates, which runs under the Sea of Marmara and crosses the Peninsula to the Gulf of Saros, forming the northern, rifted and strongly rectilinear margin of the peninsula and the Dardanelles Straits, and separating it from the rest of Thrace. This fault zone has predominantly strike-slip movement, and is complex, as other branches of it form the Dardanelles and the Sea of Marmara, and is still active today. During the Neogene fault movement developed a trans-tensional basin and produced the Sea of Marmara, with a maximum depth of 1000 metres, and led to the deposition of the thick Neogene sediments on either side of the Dardanelles. The Gallipoli Peninsula is therefore mostly composed of Palaeogene and Neogene sediments in a simple, relatively undisturbed relationship (Fig. 1.2). The oldest Palaeogene beds consist of Middle and Upper Eocene sediments that form the northern coast of the Peninsula. These Eocene beds are succeeded by continental Oligocene deposits, followed by marine sediments of Miocene age. Continental Pliocene caps most of the upland areas, and Quaternary alluvium and related sediments are found in valleys. It is these Pliocene-Quaternary rocks that were to have a major impact on the development of the Gallipoli Campaign at ANZAC.

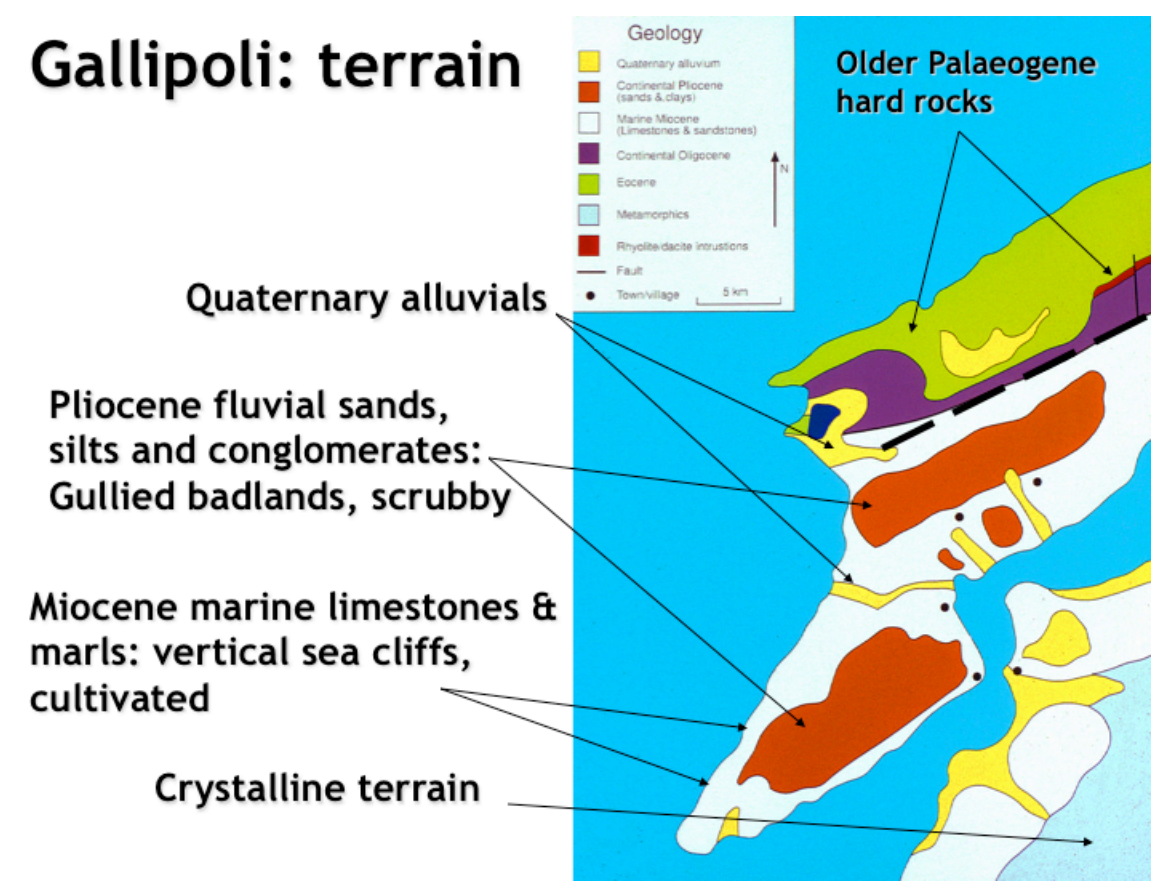

Fig. 1.2 The basic geology of the Gallipoli Peninsula, showing the Miocene soft sediments capping the Sari Bair range at Anzac. (Based on illustration in Doyle and Bennett 1999) 


\section{Relief}

The relief of the southern part of the Gallipoli Peninsula is relatively subdued, with a series of ridges in the north and two northeast-southwest trending plateaux in the south (Fig. 1.2). The southern plateaux are formed from Pliocene sediments, overlying bedded Miocene limestones. The margins of the plateaux are heavily dissected, forming a complex network of sharp-crested interfluves. In most cases the slopes are vegetated with scrub, but where the slopes are marked, there is active downcutting and erosion, creating a heavily dissected 'badland', typical of arid environments with soft, easily eroded sediments. The northern margin of the Sari Bair plateau is marked by a fault line scarp, and this is indicative of the active nature of the uplift caused by movement along the North Anatolian Fault Zone, itself exacerbating the erosion. Beneath the steep upper face of the scarp the slopes are heavily gullied and are barren of vegetation, forming classic 'badland' topography. In the southeastern part of the peninsula, the slopes of the Kilid Bahr Massif are strongly gullied, in some cases forming deep ravines. These ravines exploit the structural grain of the Peninsula, to give a parallel-alignment to the drainage of the southern peninsula.

The majority of rivers within the southern Gallipoli Peninsula are seasonal, and most valleys are dry for much of the year. Exceptions occur in the northern part of the study area, on the margins of the Suvla Plain, where there are some perennial streams. All the major lithological units have potential as aquifers. However, it is clear from studies of Neogene and younger sediments on the southern margin of the Dardanelles that the main aquifer potential lies with the Miocene limestones and the Quaternary alluvial deposits.

\section{The ANZAC landings, 25 April 1915}

The Australian and New Zealand Army Corps were to be landed at the beach (' $Z$ ' Beach) north of Gaba Tepe (Fig. 1.1), facing the formidable, dissected landscape of the Sari Bair Range. The range terminated to the northwest, its steep face created by the actions of fractures in the underlying soils, part of the same fault system that had created the Dardanelles. The underlying rocks were easily eroded from fluvial action and intermittent rainfall over centuries producing a rugged landscape. The vegetation consists of a low, unforgiving scrub; with rough and easily disturbed soils, resulting in little flat ground.

Behind ' $Z$ ' Beach (soon to be dubbed Brighton Beach after its namesake in Melbourne, Australia), three parallel ridges (first, second and third) seemed to provide the best means of assaulting the peak in the initial stages of the operation. These ridges are a function of the activity of the North Anatolian Fault system, and mirror the structural grain of the Peninsula. If the ANZACS could get ashore in this inhospitable place, then they could clamber up the slopes that led to Second 
Ridge; moving through the scrub along the ridge, where they would be in a position to 'take the high ground' and dominate the ridge top. From here there would be views across Suvla Bay and its plain to the northwest, and back down to the southeast in the direction of Helles. ' $Z$ ' Beach (between Gaba Tepe and Ari Burnu) was to be assaulted by the Anzacs at one hour before dawn, in an effort to maximize surprise, and to try and reach the first positions before daybreak. Three battalions of the Australian 3rd Brigade (together with supporting troops) would lead the assault landed from seven destroyers, which were to approach close in to the beach. The main force would land from transports (Aspinall-Oglander 1929; Rhodes James 1965; Travers 2001; Carlyon 2003; Prior 2003; Doyle 2011).

With the three ridges leading to the summit of the Sari Bair Range (Fig. 1.3) as the target, and Second Ridge just behind the beach, the 3rd Brigade was ordered advance over its slopes, thereby gaining - and holding Third Ridge. Following on closely, the Australian 2nd Brigade, would then be in a position to advance up the ridge, taking the nearest summits, Chunuk Bair at the flat plateau top joined by the three ridges, and 'Scrubby Knoll' a prominent feature on Third Ridge. The main force would then arrive to press on to a hill known as Mal Tepe, on the Dardanelles side of the Peninsula - which, it was hoped, would serve as a strong point that would help secure the Dardanelles defences. In taking the ridge tops, the ANZACs hoped to be able to deny them to the enemy - and ultimately link up with the British advancing from Cape Helles to conquer the northern shore of the Dardanelles and silence the guns.

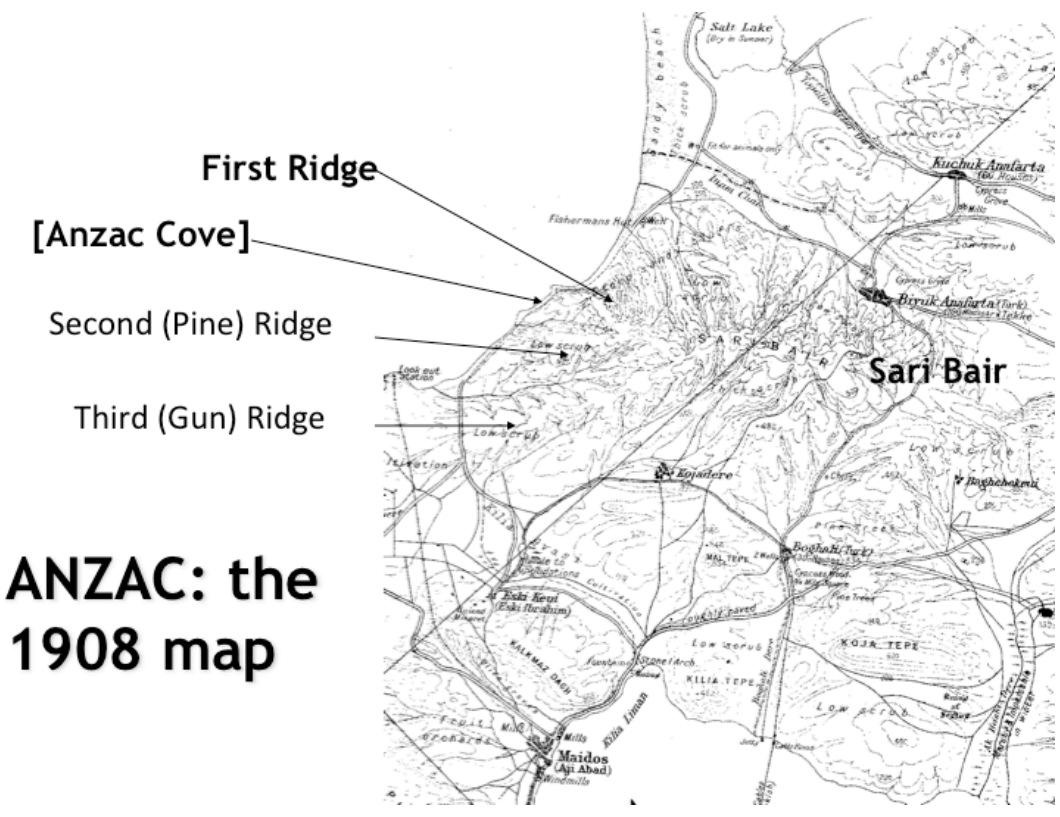

Fig. 1.3 The 1908 map, showing the continuous nature of First Ridge, a feature found to be impassable on 25 April 1915. The location of the Second and Third ridges, and the summit of the Sari Bair Plateau, is marked 
Gaining the shore at about $4.30 \mathrm{am}$, the Australians struggled up the shingle beach in their combat equipment. The water was deeper than expected as the soldiers leaped out of the boats; several must have been dragged under. Ahead of them were unfamiliar slopes that would lead up to the top of Sari Bair. Small arms fire was directed at them by the Ottoman defenders. It was heaviest at the northern part - the promontory known as Ari Burnu, and close to the small ramshackle building known as Fisherman's Hut. But this was not the only resistance facing the Australians. In front of them were the first slopes that they knew would lead up to the top of the Sari Bair range. The Australian battalions struggled to the top of a slope vegetated with thick scrub that was later to be called Plugge's Plateau a small flat-topped extension of what was the First Ridge (Fig. 1.3). They were unable to push on - confronting them was a bald, narrow ridge that the forces of nature had eroded from both sides - the Razor Edge. This was to be impassable; north of this feature was a forbidding bowl of bare earth that sat at the foot of what the soldiers (in memory of their time in Egypt), would later call 'The Sphinx'. This steep-sided cliff, part of Walker's Ridge, that had been created by the erosion of a particularly hard band of cemented conglomerate that was resistant to weathering. This was in contrast to most of the Sari Bair Range, made up of fine Miocene sediments that were easily eroded by both wind and water action, creating a myriad of gullies, sharp spurs and innumerable dead-ends. Devoid of much water, these soils promoted the growth of stunted bushes and shrubs. The Razor's Edge came as a complete surprise to the Australians. The 1908 vintage map supplied to the troops indicated a continuous ridge that could be easily traversed (Fig. 1.3). This was not to be the case, and became a major point of contention in post-war discussions of terrain intelligence failure, starting with the British Official History (Aspinall-Oglander 1929; see Chasseaud \& Doyle 2004).

For the men landing north of Ari Burnu, not only would the harsh terrain of the Sphinx and Walker's Ridge be in their way, so would the fire of the defending Ottomans at Fisherman's Hut. The next wave of men came ashore from the boats also released by the seven destroyers standing off the coast. Now daylight, the boats were more spread out, delivering men onto a beach that was in the order of 1500 yards wide, part of them to the north of Ari Burnu, the remainder to the south. By 4.45 am, some 4000 men of the ANZAC covering force were released into the confusing and inhospitable badland landscape of the sector - much easier to defend than attack. Under attack from the defenders in the north, and facing uncertain terrain in front of them, it was difficult to know in what direction they should press ahead. Led my officers as unsure of the terrain as their men, the ANZACs scrambled through the unforgiving terrain towards their target, Hill 971 and 'Baby 700' at the junction of the three main ridges.

The remainder of the Australian troops began landing from the transports at $5.30 \mathrm{am}$, the press of men adding to the confusion of those already onshore. As they advanced farther up the coast past Ari Burnu and Walker's Ridge, and close to the 'Fisherman's Hut', the ANZAC troops were once more engaged by the Ottoman defenders - at a high cost to the attackers. Men from the second wave were pressed into the attack. The commander of the Covering Force was aware that he 
had to press on from the beaches to capture the Third Ridge (Fig. 1.3), hold it and force his troops on to the high ground. Yet with passing time, the cohesion of his fighting units was breaking down, and it was difficult to identify just who was where, with small groups of men engaged in their own battles with the landscape. It was more realistic to try and concentrate on Second Ridge, securing its length from close to Hell Spit, at the southern end of Anzac Cove, upwards from the beach until the ridge coalesced with the great mass of summit of the Sari Bair Range. Though some scouts had reached Scrubby Knoll at around 9.00 am, briefly viewing the Narrows in the distance, they soon had to withdraw. No other ANZACs would stand on the knoll during the war.

With Third Ridge seemingly out of his grasp, the ANZAC commander directed his forces to form strong posts along the edge of the Second Ridge, posts that would hold throughout the campaign (soon to become named after their commanders - 'Courtney's', 'Steele's' and 'Quinn's'; Fig. 1.4). Baby 700, sat at the junction of Second Ridge with the main mass of the mountain, would also have to be held. Not for the last time, the deep, scrub-filled gully that divided the First from the Second Ridges, Monash Valley, would serve as a route towards the apex of the ANZAC line. The line would also have to hold across the broader expanse of the 400 Plateau, a wider area on Second Ridge covered in dense scrub. (The eastern part of the Plateau, soon to be christened 'Lone Pine' after its single pine tree, was to see some of the bloodiest hand-to-hand fighting of the whole campaign, in August).

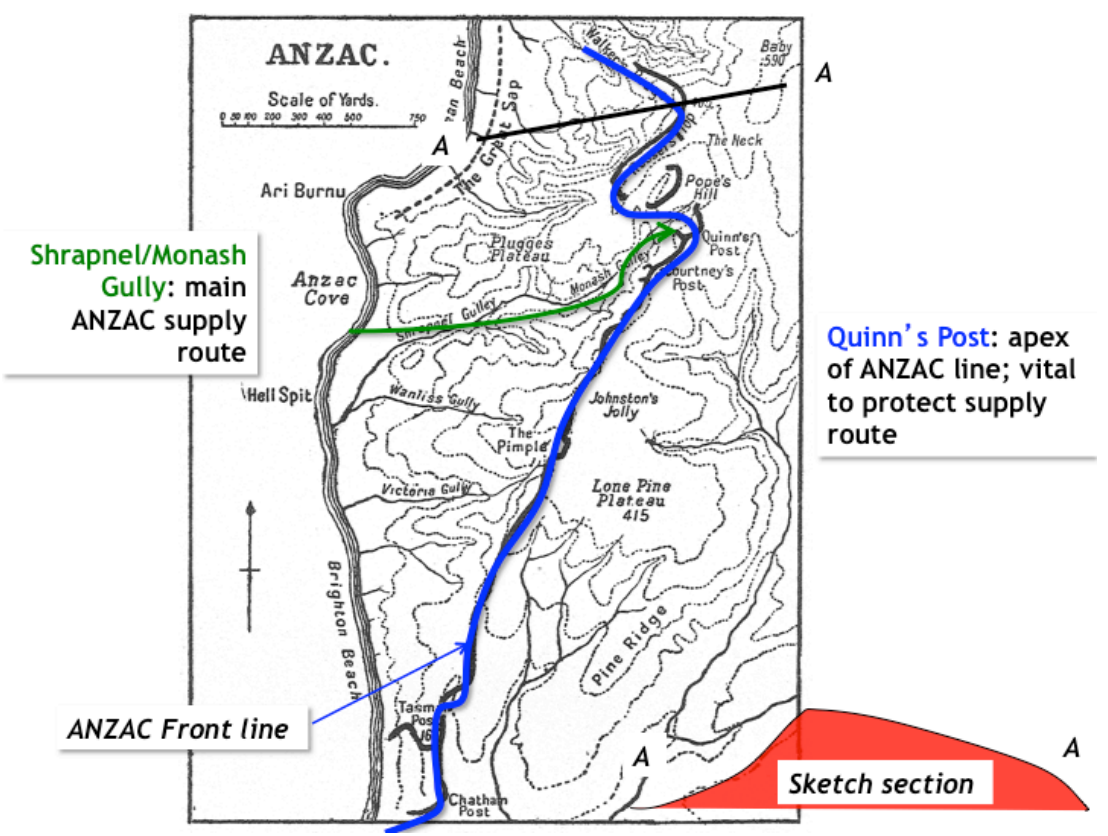

Fig. 1.4 Stalemate at Anzac: the relatively static trench lines, defining the most dissected part of the Sari Bair range. (Map from Callwell 1929) 
On Second Ridge, a flat plateau that was the scene of fierce fighting within the scrub vegetation in the first hours of the campaign, still presented difficulties. Attack and counterattack followed each other over possession of Baby 700. Holding out until $4.00 \mathrm{pm}$, the ANZAC line finally broke, the hill lost, when the Ottomans made a concerted effort to drive them from it. With the benefit of artillery support (naval gunfire in this opening part of the campaign), the ANZAC line melted away, its survivors streaming back over the narrow saddle of land that connected First Ridge with the plateau top.

As night descended on the scene, both defenders and attackers were in a perilous state. The line was held in an arc rising from the beach along Second Ridge (leading to 400 Plateau) through the isolated posts (Steele's, Courtney's and Quinn's) to the head of Monash Gully; from there it descended down to the sea on the other side of the Sphinx, along Walker's Ridge. The front line formed an arc of rilled and gullied ground, just less than one and a half miles in length, its greatest penetration amounting to no more than a mile. Having landed and dug-in, the ANZACs were now told to wait events, and hold the line. In total, 15,000 ANZAC troops had landed; but there were now 2,000 dead and wounded, with the living crowded into open boats waiting to be re-embarked.

\section{Trench warfare}

With the landings stalemated, came the onset of trench warfare (Fig. 1.4). Making the best of it, the Australians and New Zealanders fell into a routine that would ensure their part of the line was protected from Ottoman attacks. Everywhere in the frontline the conditions were poor. The relatively soft Pliocene sediments enabled the relatively rapid development of rudimentary trench systems, although this was hampered in the opening hours of the campaign by an absence of adequate construction tools, and by the degree of root penetration. By the end of the campaign, the trench systems were complex with a parallel underground system of tunnels and saps. In addition, many terraces were cut in the reverse slope to provide rudimentary dwelling areas (Aspinall-Oglander 1932; Rhodes James 1965; Carlyon 2003; Stanley 2005).

In general, few drainage problems were encountered early in the campaign, given the paucity of rainfall, in the summer months at least, the relative permeability of the trenches, and the depth to the water table. Trench construction was nevertheless an important consideration for the military engineers. Revetment was usually achieved using locally derived or shipped in timber, and both sides used covered trench systems, roofed by timber baulks and earthworks, in order to mitigate against the effects of shrapnel and small arms fire, although largely useless against direct hits from high explosive shells. Covered trench systems were created and there was extensive use of loopholes for snipers. New trenches were often dug by the use of shallow tunnels, which were then roofed with timber before loopholes were cut (Aspinall-Oglander 1932; Prior 2009). 
As with the Western Front, dugouts at Gallipoli varied from the deep, shellproof dugout to the shallow recess or 'funk-hole' intended only as a limited shelter (Doyle and Bennett 1999). Extensive dugout systems were cut into the seawards slopes of the Sari Bair Plateau providing shelter for a variety of administrative and service personnel. These were linked to the beaches by transport routes along gullies on the scarp slope of the plateau in the ANZAC Sector. Transport routes to the beaches were hazardous; here Monash Gully, leading to Shrapnel Gully, was be developed as a transport thoroughfare, with pack animals moving to and fro (Fig. 1.4).

While ostensibly static, the frontline trenches were actually alive with activity. In an echo of ancient siege warfare, mines were dug by both sides beneath each other's forward trenches, in order that explosives could be placed to destroy the trenches above (Aspinal-Oglander 1932; Branagan, 1987; Stanley 2005; Prior 2009). Mining was also used for the construction of dugouts intended as dressing stations, operating theatres, headquarters and for other uses (Fig. 1.5). Harder conglomeratic levels (such as that at 'The Sphinx' were exploited as mine gallery roofs, though were hard to cut down through (Fig. 1.6). Nevertheless, mines were dug throughout the frontlines, but perhaps none so much as at Quinn's Post (Stanley 2005), at the head of Monash Gully, the main supply line (Fig. 1.5). It was described by some as the key position at Anzac:

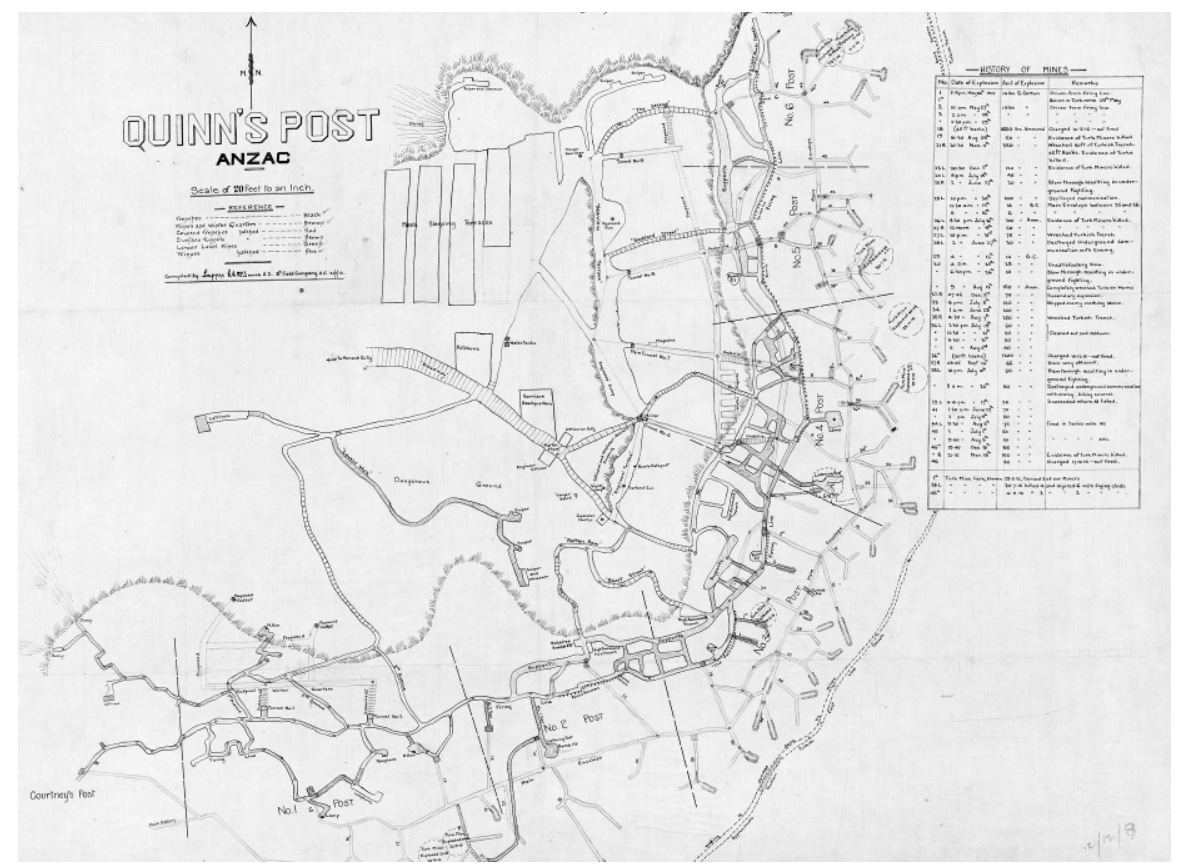

Fig. 1.5 A contemporary map of mining activity close to Quinn's Post, ANZAC Sector, 1915 


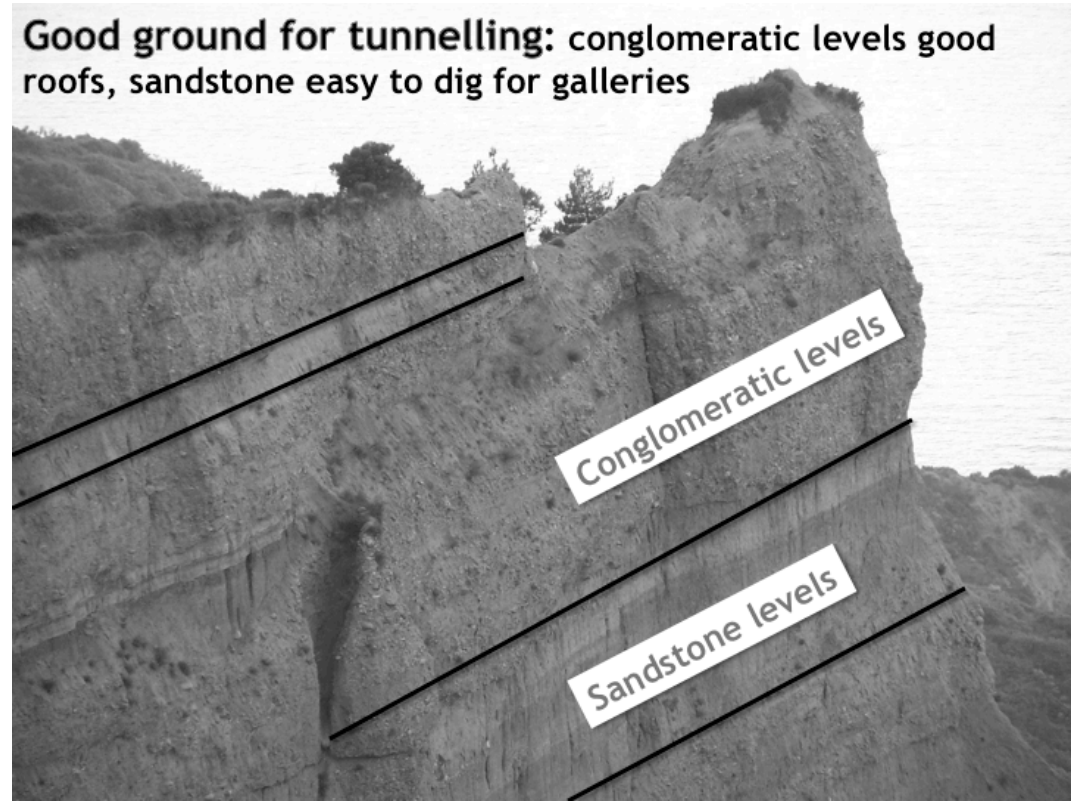

Fig. 1.6 Harder conglomeratic levels within the sediments at Anzac, here helping to form the distinctive feature known as 'The Sphinx', the main flank of which is illustrated

\begin{abstract}
Quinn's had a fatal fascination for the Turk. Quinn's was a position that was to be held at all cost; with limited space, a complex terrace had to be constructed to its rear in order to provide sufficient room to create adequate fire and communication trenches. During May the enemy commenced mining in earnest, and this was a serious menace to the safety of the ANZAC area. Successful underground operations by the enemy would mean that Quinn's might slide down into Monash Gully, so vigorous countermining was resorted to. The object of this countermining was to get under or near the opponent's drives [tunnels], and destroy them by means of small charges. Major Fred Waite, NZ Engineers (Waite 1921).
\end{abstract}

Water supply was a major pre-occupation in the ANZAC Sector, as elsewhere on the peninsula, though the combination of geological circumstances discussed above meant that it was perhaps more acute here. The German commander, Linman von Sanders considered that one of the most decisive factors responsible for the Turkish success was the availability of water behind their lines (Hamilton 1920; Nevinson 1920; Aspinall-Oglander 1932; Doyle \& Bennett 1999, 2002; Prior 2009); something that was lacking for the Allies One of the biggest issues was a lack of reliable groundwater supplies in the ANZAC Sector. Here, the main limestone aquifer found in the southern peninsula (Fig. 1.2) was at depth, overlain by largely dry sediments. Some water supplies were found perched on impermeable strata, but were difficult to accurately locate (Beeby-Thomson 1924). Some seasonal exploitation of water courses in the Sector was theoretically possible, but 
like the perched sources were ephemeral. Many of the wells dug in the surrounding gullies began to dry up with the approach of summer, and though others were found at depth. This meant that the daily ration from local sources in the 1st Australian Division was rarely more than one third of a gallon per man; today, in arid conditions, two gallons might be expected for combat effectiveness (Anon 2012). Most water supplies for these areas was from imported water (Aspinall-Oglander 1929, 1932), and the large water-lighters used had to be towed from Alexandria and Malta and moored alongside the piers at Anzac Cove. The water could then be pumped by hand into iron tanks on the beach, whence it was taken by mules to other tanks in the hills, and thence by hand to the troops holding the line.

Later, a pumping plant and a number of larger storage tanks were obtained from Egypt. These were hauled to specially constructed platforms on the slopes of Plugge's Plateau, Walkers Ridge and other points near the front line. They were connected to the beach, and thereafter water could be pumped straight into them from the lighters, and then distributed to smaller tanks by gravitation (AspinallOglander 1932, p. 117).

\footnotetext{
As to water, that element of itself was responsible for a whole chapter of preparations. An enormous quantity had to be collected secretly, and as secretly stowed away at Anzac, where a high-level reservoir had to be built, having a holding capacity of 30,000 gallons, and fitted out with a regular system of pipes and distribution tanks. A stationary engine was brought over from Egypt to fill that reservoir. Petroleum tins, with a carrying capacity of 80,000 gallons, were got together, and fixed up with handles, etc. General Sir Ian Hamilton (1920).
}

\section{Discussion}

The geological and topographical issues of the ANZAC Sector were extremely challenging. The ANZACs were committed here in April 1915 as with their 'Colonial experience' in Australia it felt that they might be best suited to the terrain. That terrain was broken, gullied and rilled, the result of millennia of fluvial erosion of weak Pliocene sediments - held up here and there by more coherent beds of conglomeratic material, creating a feature named by the ANZAC troops as the Sphinx (Fig. 1.6). Such hard bands could be breached, however, and such breaches meant that potential routes, such as that presented tantalisingly, but erroneously, by the 1908 topographical map (Fig. 1.3), were reduced to razor-sharp ridges with precipitous drops. This has been argued as being a significant factor in the failure to make progress to the top of Sari Bair on the first day; though there are other reasons, such as lack of experience of the attacking troops (AspinallOglander 1929; Rhodes James 1965; Travers 2001; Carlyon 2003; Prior 2009).

The challenging nature of the terrain also meant that communication between the attacking troops was reduced, and that the momentum of the attackers was easily spent. This resulted in the Australian and New Zealand troops establishing a front line that was to cling to the seaward side of the Sari Bair scarp, but would 
not reach the ridge tops. This line formed an arc that was difficult to break out from, and which was difficult to fortify and defend. The defensive line thus created was actually series of outposts; outposts that would require considerable engineering effort to extend and fortify. It also meant that artillery fire up towards the Ottoman lines was limited in its effectiveness; the ANZACs were mostly only equipped with low trajectory field guns that would have difficulty sighting their enemy - or use naval guns from off shore. Mine warfare would be resorted to by both sides.

Like most other problems, supply issues were magnified at Anzac; all men and materiel would have to travel up the gullies that led to the front line, up Shrapnel and Monash gullies to Quinn's and other fortified positions. Water in particular was a considerable issue, especially so since there was no opportunity to exploit aquifers, and that water had to be derived from the beach, imported from Egypt. It was these issues, as much as the failure to exploit early momentum, that would see the failure of the campaign at Anzac, and that would see the withdrawal in December. It would also ensure that the battles of August, intended to break out of the ANZAC Sector would be the bloodiest of the campaign, and would still not create the desired result - the break through that would silence the guns of the Dardanelles, remove the threat of the minefields, and allow the Allied ships through. The terrain had significantly impeded the ANZACs at Gallipoli, an unfortunate accident of geography bringing the least favourable geology of the whole peninsula - Miocene-Pliocene sediments that tended to badlands - to the very spot where the Anzacs would land and attempt to prosecute their war against the Ottomans.

\section{References}

Anon, 2012, Military Water Supply, Think Defence: 4 March 2012 http://www.thinkdefence.co.uk/2012/03/military-water-supply/DOI $\quad 19.01 .13 \quad$ (accessed March 2012).

Aspinall-Oglander, C.F., 1929, History of the Great War: Military Operations Gallipoli, Volume 1. Inception of the Campaign to May 1915: London, UK, W. Heinemann Ltd.

Aspinall-Oglander, C.F. 1932, History of the Great War: Military Operations Gallipoli, Volume 2. May 1915 to the Evacuation: London, UK, W. Heinemann Ltd.

Beeby-Thomson, A., 1924, Emergency water supplies for military, agricultural and colonial purposes: London, UK, Crosby Lockwood and Son.

Branagan, D., 1987, The Australian Mining Corps in World War I: Bulletin and Proceedings of the Australian Institute of Mining and Metallurgy, v. 292, p. 40-44.

Callwell, C.E., 1924. The Dardanelles: London, UK, Constable and Company Ltd.

Carlyon, L., 2003, Gallipoli: London, UK, Bantam.

Chasseaud, P. and Doyle, P., 2004, Grasping Gallipoli: Terrain, Maps and Failure in the Dardanelles: Staplehurst, UK, Spellmount Ltd.

Crawley, R., 2014, Climax at Gallipoli: Norman, OK, USA, University of Oklahoma Press

Doyle, P., 2008, Six VCs before Breakfast, Terrain and the Gallipoli Landings 1915, in Nathanail, C.P., Abrahart, R.J. and Bradshaw, R.P., eds., Military Geography and Geology: History and Technology: Nottingham, UK, Land Quality Press. 
Doyle, P., 2011, Battle Story: Gallipoli, 1915: Stroud, UK, The History Press.

Doyle, P. and Bennett, M.R., 1999, Military geography: the influence of terrain on the outcome of the Gallipoli Campaign, 1915: Geographical Journal, v. 165, p. 12-36.

Doyle, P. and Bennett, M.R., 2002, Terrain and the Gallipoli Campaign, 1915, in Doyle, P. and Bennett, M.R., eds., Fields Of Battle, Terrain in Military History: Dordrecht, the Netherlands, Kluwer Academic Publishers.

Hamilton, I., 1920, Gallipoli Diary: London, UK, Arnold.

Nevinson, H.W. 1920. The Dardanelles Campaign: London, UK, Nisbet \& Co Ltd

Prior, R. 2009. Gallipoli, The End of the Myth: New Haven, CT, USA, Yale University Press

Rhodes James, R., 1965, Gallipoli: London, UK, Batsford.

Stanley, P., 2005, Quinn's Post: Anzac, Gallipoli: Melbourne, Australia, Allen \& Unwin.

Ternek, Z., Erentöz, C., Pamir, H.N. and Akyürek, B., 1987, 1:500 000 Ölçekli Türkiye Jeoloji Haritasi (Explanatory Text of the Geological Map of Turkey): Istanbul, Turkey, Ankara: Maden Tetkik ve Arama Genel Müdürlügü Vayinlarindan.

Travers, T. 2001. Gallipoli 1915: Stroud, UK, Tempus

Waite, F., 1921, The New Zealanders at Gallipoli: Auckland, NZ, Whitcombe \& Tombs. 